\title{
Tetrandrine Inhibits Epithelial-Mesenchymal Transition in IL-6-Induced HCTI I 6 Human Colorectal Cancer Cells
}

\author{
Shih-Chang Tsai $\mathbb{D}^{\prime}$ \\ Wei-Chei Wu' \\ Jai-Sing Yang ${ }^{2}$ \\ 'Department of Biological Science and \\ Technology, China Medical University, \\ Taichung, Taiwan, Republic of China; \\ ${ }^{2}$ Department of Medical Research, China \\ Medical University Hospital, China \\ Medical University, Taichung, Taiwan, \\ Republic of China
}

\begin{abstract}
Introduction: Patients with colorectal cancer (CRC) often develop distant metastases, which significantly reduces the 5-year survival rate. Epithelial-mesenchymal transition (EMT) is a crucial process for the invasion and metastasis of cancer cells. Tetrandrine has been reported to inhibit the viability and EMT of CRC cells; however, to the best of our knowledge, the molecular mechanism remains undetermined.

Methods: The MTT assay was used to determine HCT116 cell viability. Wound healing and Transwell assays were used to determine that cell migration and invasion, respectively. Western blotting analysis was performed to detect the expression of migration-related genes. Four different lengths of the E-cadherin gene promoter were constructed and cloned into pGL3 reporter plasmids to evaluate E-cadherin gene promoter activity.

Results: The results of the MTT assay revealed that tetrandrine inhibited HCT116 cell viability, with an $\mathrm{IC}_{50}$ value of $7.2 \mu \mathrm{M}$ following $24 \mathrm{~h}$ of treatment. Tetrandrine inhibited IL6 -induced cell migration and invasion, respectively. Tetrandrine regulates the expression of migration-related genes in IL-6-stimulated HCT116 cells. Tetrandrine significantly downregulated the expression and enzyme activity of MMP-2 in IL-6-stimulated HCT116 cells. In addition, tetrandrine restored E-cadherin gene promoter activity.
\end{abstract}

Conclusion: The findings of the present study suggested that tetrandrine may inhibit EMT in IL-6-stimulated HCT116 cells; therefore, it may represent a potential drug for CRC.

Keywords: tetrandrine, IL-6, epithelial-mesenchymal transition, colorectal cancer

\section{Introduction}

The formation of tumors is caused by abnormal cell growth and division. Malignant tumors are characterized by rapid proliferation, and are highly invasive and metastatic. Cancer cell invasion and migration occur as a consequence of epithelialmesenchymal transition (EMT) ${ }^{1,2}$ and not as a random event. ${ }^{3}$ The communication between cancer cells and cells in the microenvironment has been suggested to promote cancer progression and metastasis, which is associated with a poorer prognosis for patients. ${ }^{4}$ Cells interact with each other by secreting hormones, chemokines and hydrolytic enzymes. Cancer-associated fibroblasts were found to secrete IL-6 to promote the metastasis of gastric cancer cells. ${ }^{5}$ Therefore, determining the mechanisms underlying the crosstalk between cancer cells and the surrounding microenvironment has become an important topic in cancer treatment research.

E-cadherin is a $120-\mathrm{kDa}$ glycoprotein located on chromosome $16 \mathrm{q} 22.1$ and is an important adhesion molecule found between epithelial cells, where it regulates
Correspondence: Shih-Chang Tsai

Department of Biological Science and Technology, China Medical University, 100

Sec. I, Jing-Mao Road, Taichung, 406040,

Taiwan, Republic of China

Tel +886 4-2205-3366 ext 2518

Fax +886 4-2299-4787

Email sctsai@mail.cmu.edu.tw 
cell morphology, migration and adhesion. ${ }^{6}$ The E-cadherin protein has extracellular, transmembrane and intracellular domains. The intracellular domain of E-cadherin is bonded by $\alpha$-catenin and $\beta$-catenin or $\gamma$ catenin, and connects with the actin cytoskeleton to maintain cell-to-cell adhesion. ${ }^{7,8}$ The expression status of E-cadherin has often been regarded as an important indicator of cancer cell metastasis. ${ }^{9}$ Once cells are metastatic, the expression levels of E-cadherin were found to be downregulated. ${ }^{10}$ The E-cadherin promoter contains numerous putative transcription factor binding sites, including the enhancer box (E-box), of which the DNA sequence is CANNTG ( $\mathrm{N}$ represents any base). Several transcription factors, such as snail family transcriptional repressor 1 (SNAIL), ${ }^{11}$ snail family transcriptional repressor 2, ${ }^{12}$ zinc finger E-box binding homeobox (ZEB)1, ZEB2 ${ }^{13}$ and twist family bHLH transcription factor 1 (Twist1), ${ }^{14}$ were discovered to interact with the E-box to repress E-cadherin transcription. The downregulation of E-cadherin expression levels was reported to trigger the metastasis of cancer cells. Therefore, determining novel methods to regulate the interaction between the E-cadherin gene promoter and transcription factors is an important focus of research in the study of cancer cell metastasis.

Colorectal cancer (CRC) is one of the most common types of cancer and its incidence continues to increase annually. Familial adenomatous polyposis is a genetic condition caused by defects in the adenomatous polyposis coli (APC) gene, that cause abnormalities in the regulation of the downstream Wnt signaling pathway are risk factors for CRC. ${ }^{15} \mathrm{CRC}$ is also caused by a multistep series of gene mutations, including the overactivation of oncogenes such as Ras, Src and Myc, and the inactivation of tumor suppressor genes, such as p53 and APC. ${ }^{16}$ Environmental factors have also been discovered to be risk factors for CRC; for example, poor dietary and lifestyle habits, such as smoking, alcohol abuse and excessive intake of red meat and processed foods, have also been reported to cause genetic abnormalities and eventually lead to the formation of CRC. ${ }^{17,18}$

The current treatment methods for CRC include surgery, radiation therapy, chemotherapy and targeted therapy. The early diagnosis of CRC and the subsequent treatment with surgery and drug supplementation was shown to be beneficial to the outcome of patients. However, the prognosis of patients with metastatic CRC was significantly worse. ${ }^{19}$
Therefore, it is crucial to identify effective methods for the prevention and treatment of metastatic CRC.

Tetrandrine is a type of bisbenzylisoquinoline alkaloid extracted from the roots of Stephaniae tetrandrae. ${ }^{20}$ Tetrandrine has been used as an anti-inflammatory ${ }^{21}$ and anti-hypertensive agent, ${ }^{22}$ and was also found to protect the heart ${ }^{23}$ and regulate pulmonary blood vessel and airway smooth muscle contraction. ${ }^{24}$ Tetrandrine is currently used in the clinic to treat patients with silicosis, rheumatoid arthritis and pulmonary hypertension. ${ }^{25,26}$ Recently, numerous studies have demonstrated that tetrandrine exerted anticancer effects. For example, tetrandrine inhibited the proliferation and angiogenesis of glioma cells in rats ${ }^{27}$ and promoted the apoptosis of oral cancer cells via inhibiting autophagy to promote energy deficiency. ${ }^{28}$ In addition, tetrandrine reversed the metastasis of bladder cancer cells by downregulating the expression of GLI family zinc finger $1 .{ }^{29}$ Notably, tetrandrine has been suggested to represent a potential therapeutic agent in numerous types of cancer. Furthermore, a previous study has indicated that tetrandrine may be relatively non-toxic to the human body. ${ }^{30}$ Thus, we hypothesized that tetrandrine may represent a potential novel anticancer drug, which may be due to its ability to regulate cancer cell metastasis. The present study aimed to investigate the efficacy of tetrandrine in CRC metastasis. In addition, the study sought to determine the molecular mechanisms underlying the anti-CRC effects of tetrandrine in an IL-6-stimulated tumor environment.

\section{Materials and Methods}

\section{Chemicals and Reagents}

Tetrandrine, IL-6, MTT, crystal violet and gelatin were obtained from Sigma-Aldrich; Merck KGaA. DMEM, cosmic calf serum (CCS), penicillin, streptomycin, trypsinEDTA and Opti-MEMTм I Reduced Serum medium were purchased from Gibco; Thermo Fisher Scientific, Inc. Primary antibodies against E-cadherin and FOXA1, and HRP-conjugated secondary antibodies were obtained from Cell Signaling Technology, Inc. The anti-phosphorylated (p)-STAT3 primary antibody was obtained from Santa Cruz Biotechnology, Inc. and the anti-ZEB1 primary antibody and ECL reagent were obtained from GeneTex, Inc. PVDF membranes were obtained from MilliporeSigma.

\section{Cell Lines and Culture}

The HCT116 human CRC cell line was obtained from the American Type Culture Collection. Cells were cultured in 
DMEM supplemented with $10 \%$ CCS, $100 \mathrm{U} / \mathrm{mL}$ penicillin and $100 \mu \mathrm{g} / \mathrm{mL}$ streptomycin, and maintained in a humidified environment with $5 \% \mathrm{CO}_{2}$ at $37^{\circ} \mathrm{C}$.

\section{Cell Viability Assay}

Cell viability was assessed using an MTT assay, as previously described. ${ }^{31}$ Briefly, $8 \times 10^{3}$ HCT116 cells/well were seeded into 96-well plates (Thermo Fisher Scientific, Inc.), allowed to attach overnight and then treated with $1.25,2.5,5,7.5$ or $10 \mu \mathrm{M}$ tetrandrine for 24 h. Following the incubation, MTT $(0.5 \mathrm{mg} / \mathrm{mL})$ was added to each well and incubated for $3 \mathrm{~h}$. The supernatant was subsequently discarded and DMSO was added to each well to dissolve the formazan crystals. The absorbance was measured at a wavelength of $570 \mathrm{~nm}$ using an ELISA reader; the absorbance of the control cells was set to $100 \%$ and each experimental group (six replicate wells/ concentration) was normalized to the control group. At least four independent experiments were performed.

\section{Wound Healing Assay}

A total of $1 \times 10^{5}$ HCT116 cells/well were seeded into both sides of a culture insert (Ibidi $\mathrm{GmbH}$ ) in 6-well plates (which was used to create a $500-\mu \mathrm{m}$ diameter gap between the cells in the well), then cultured with $70 \mu \mathrm{L}$ DMEM supplemented with $10 \% \mathrm{CCS}$ at $37^{\circ} \mathrm{C}$ overnight. After the cells had attached to the surface of the plates, the inserts were gently removed and the cells were incubated in $2 \mathrm{~mL}$ DMEM supplemented with $1 \% \mathrm{CCS}, 0,1.25,2.5$ or $5 \mu \mathrm{M}$ tetrandrine and $50 \mathrm{ng} / \mathrm{mL}$ IL-6. Images of the cells in the wounded monolayer were captured at 0 and $24 \mathrm{~h}$, and the cell migration percentage was determined by measuring the gap sizes in three fields of view under a light microscope (Leica $\mathrm{GmbH}$; magnification, x100). The migratory distance was semi-quantitatively analyzed using ImageJ software $1.51 \mathrm{u}$ (National Institutes of Health). ${ }^{32}$

\section{Transwell Migration and Invasion Assays}

The upper chambers of 24-well Transwell plates (Costar; Corning, Inc.) were precoated with or without Matrigel for the invasion and migration assays, respectively. ${ }^{33}$ Briefly, $1 \times 10^{5}$ cells were seeded into the upper chambers of the plates and cultured with DMEM supplemented with $1 \%$ CCS, $0,1.25,2.5$ or $5 \mu \mathrm{M}$ tetrandrine and $50 \mathrm{ng} / \mathrm{mL}$ IL-6 for $24 \mathrm{~h}$ at $37^{\circ} \mathrm{C}$. DMEM supplemented with $10 \% \mathrm{CCS}$ was plated into the lower chambers. Following the incubation, the non-migratory or -invasive cells remaining in the upper chambers were removed using a cotton swab, while the cells in the lower chambers were fixed with cold methanol, stained with $0.5 \%$ crystal violet for $1 \mathrm{~h}$ at room temperature and then visualized using a light microscope (Leica $\mathrm{GmbH}$; magnification, x100). The migratory or invasive cells were semi-quantified using ImageJ software $1.51 \mathrm{u}$.

\section{Gelatin Zymography Assay}

A total of $8 \times 10^{5}$ HCT116 cells were seeded into 24-well plates and allowed to attach overnight. The medium was subsequently changed to serum-free medium containing 0 , $1.25,2.5$ or $5 \mu \mathrm{M}$ tetrandrine and $50 \mathrm{ng} / \mathrm{mL}$ IL-6, and cells were incubated for a further $24 \mathrm{~h}$ at $37^{\circ} \mathrm{C}$ prior to collection of the conditioned media. MMP-2 enzyme activity was determined using gelatin zymography, as previously described. ${ }^{33}$ Briefly, $2 \mathrm{mg} / \mathrm{mL}$ conditioned media was loaded onto SDS-PAGE gels polymerized with gelatin. After electrophoresis, the gels were renatured in $2.5 \%$ Triton X-100, then incubated in developing buffer [0.05M Tris- $\mathrm{HCl}(\mathrm{pH} 7.6), 0.05 \mathrm{M} \mathrm{NaCl}, 0.01 \mathrm{M} \mathrm{CaCl} 2$ and $0.05 \%$ Brij 35] overnight at $37^{\circ} \mathrm{C}$. The gels were subsequently stained with Coomassie brilliant blue R-250 solution and the gelatinase activity of MMP-2 was visualized as transparent bands on a blue background. The band intensity was quantified using ImageJ software $1.51 \mathrm{u}$.

\section{Reverse Transcription-Quantitative PCR (RT-qPCR)}

Total RNA was extracted from HCT116 cells using REzol $^{\mathrm{TM}} \mathrm{C} \& \mathrm{~T}$ reagent (PROtech Technologies, Inc.) and RT-qPCR was performed as previously described. ${ }^{34}$ Briefly, RNA samples were adjusted to a concentration of $50 \mathrm{ng} / \mathrm{mL}$ and mixed with $10 \mu \mathrm{M}$ forward primer, $10 \mu \mathrm{M}$ reverse primer and reagents contained within the One Step SYBR ${ }^{\circledR}$ PrimeScript ${ }^{\text {TM }}$ RT-PCR Kit II; the total volume of the positive and negative primers and the master mix was $15 \mu \mathrm{L}$. The following primer sequences were used for the qPCR: $\beta$-actin forward, 5'-CCAA CCGCGAGAAGATGA-3' and reverse, 5'-TCCATCAC GATGCCAGTG-3'; twist1 forward, 5'-ACGCTGCCCT CGGACAA-3' and reverse, 5'-TCGCTCTGGAGGACCT GGTA-3'; SNAIL forward, 5'-CCCAATCGGAAGCCT AACTACA-3' and reverse, 5'-GGGCTGCTGGAAGGT AAACTCT-3'; ZEB1 forward, 5'-CACCATCCCCATCA CCTCTAAA-3' and reverse, 5'- GCACCCTCAGCTGT GTACAAGTAA-3'; MMP-2 forward, 5'-GCGGCGGT CACAGCTACTT-3' and reverse, 5'-TTCACGCTCTTC 
AGACTTTGGTT-3'; heat shock protein 90 (HSP90) $\beta$ family member 1 (HSP90B1) forward, 5'-CAGTTTGG TGTCGGTTTCTATTCC-3' and reverse, 5'-CTGGGTAT CGTTGTTGTGTTTTGA-3'; forkhead box A1 (FOXA1) forward, 5'-CTCTAGGCAGCGCCTCGGTGA-3' and reverse, 5'-CAGCATGGCTATGCCAGACAAACCC-3'; and E-cadherin forward, 5'-ACGCATTGCCACATACAC TCTCT- $3^{\prime}$ and reverse, 5'- CCATTGGATCCTCAACTG CATT-3'.

\section{Dual Luciferase Reporter Assay}

The indicated DNA was transfected into HCT116 cells for $24 \mathrm{~h}$. Following transfection, the cells were treated with 0 , $1.25,2.5$ or $5 \mu \mathrm{M}$ tetrandrine and $50 \mathrm{ng} / \mathrm{mL}$ IL-6 for another $24 \mathrm{~h}$. Cells were subsequently harvested and lysed with PLB lysis buffer (from the Dual Luciferase Reporter assay kit; Promega Corporation), according to the manufacturer's protocol. To detect the firefly luciferase activity, $100 \mu \mathrm{L}$ Luciferase assay buffer II was added to the cell lysate, which was subsequently mixed with $100 \mu \mathrm{L}$ Stop and Glo buffer to measure the Renilla luciferase activity. To calculate the relative luciferase activity, the firefly luciferase activity was normalized to the Renilla luciferase activity, then normalized to the control sample (pGL3 sample).

\section{Western Blotting}

HCT116 cells were treated with $0,1.25,2.5$ or $5 \mu \mathrm{M}$ tetrandrine and $50 \mathrm{ng} / \mathrm{mL}$ IL- 6 for $24 \mathrm{~h}$ at $37^{\circ} \mathrm{C}$. Total protein was quantified and $100 \mu \mathrm{g}$ protein/lane was separated via $10 \%$ SDS-PAGE. The separated protein samples were subsequently transferred onto PVDF membranes and blocked with 5\% non-fat milk. The membranes were then incubated with the following primary antibodies: Anti-E-cadherin, anti-FOXA1, anti-p-STAT3, antiZEB1 and anti-GAPDH (GeneTex, Inc.). Following the primary antibody incubation, the membranes were incubated with anti-rabbit or anti-mouse HRP-conjugated secondary antibodies (1: 7000 dilution) for $1 \mathrm{~h}$ at room temperature. Protein bands were visualized using ECL reagents and semi-quantified using ImageJ software $1.51 \mathrm{u}$.

\section{Statistical Analysis}

Prism 7 was used for graphing and analyzing data. Data are presented as the mean $\pm \mathrm{SD}$ of at least three independent experiments. Significant differences between groups were determined using a Student's $t$-test.
$* \mathrm{P}<0.05$ was considered to indicate a statistically significant difference.

\section{Results}

\section{Tetrandrine Inhibits the Viability of HCTII 6 Cells}

The inhibitory effect of tetrandrine on the viability of HCT116 cells was analyzed using an MTT assay. Cells were cultured and treated with $0,1.25,2.5,5,7.5$ or $10 \mu \mathrm{M}$ tetrandrine for $24 \mathrm{~h}$. Following the treatment, the morphology of the cells was altered and had become round (Figure 1A). The viability of HCT116 cells was significantly blocked by tetrandrine at concentrations of $>2.5$ $\mu \mathrm{M}$, and the $\mathrm{IC}_{50}$ value of tetrandrine was found to be $7.2 \mu \mathrm{M}$ (Figure 1B). These data suggested that $<7.2 \mu \mathrm{M}$ tetrandrine should be used in the subsequent experiments.

\section{Tetrandrine Exerts No Significant Effect on the Migration of HCTII 6 Cells}

A previous study demonstrated that tetrandrine inhibited the metastasis of cancer cells. ${ }^{35}$ In the present study, wound healing assays were performed to determine whether tetrandrine inhibited the migration of HCT116 cells. Cells were supplemented with $1 \%$ CCS and treated with $0,1.25,2.5$ or $5 \mu \mathrm{M}$ tetrandrine for $24 \mathrm{~h}$. Tetrandrine exerted no significant effect on the migration of HCT116 cells compared with the control cells (Figure 2A and B).

\section{Tetrandrine Significantly Inhibits Migration and Invasion in IL-6-Stimulated HCTI I6 Cells}

In the tumor microenvironment, some cytokines, such as IL-6, are secreted and alter the neighboring cell behaviors. ${ }^{36}$ IL- 6 was discovered to enhance the migration and invasion of cancer cells. ${ }^{37}$ To determine whether tetrandrine inhibited IL-6-induced cell migration, wound healing assays were performed. Following stimulation with $50 \mathrm{ng} / \mathrm{mL}$ IL-6, HCT116 cell migration was increased from $23 \%$ to $54 \%$, while it was reduced from $54 \%$ to $35 \%$ by tetrandrine treatment, compared with the control cells (Figure 2C and D). In addition, Transwell assays were used to determine whether tetrandrine inhibited IL6-induced cell migration and invasion. Following stimulation with $50 \mathrm{ng} / \mathrm{mL}$ IL-6, a 1.7 -fold increase was detected in both HCT116 cell migration and invasion. Cell migration was reduced from 1.7 -fold to 0.8 -fold and invasion 


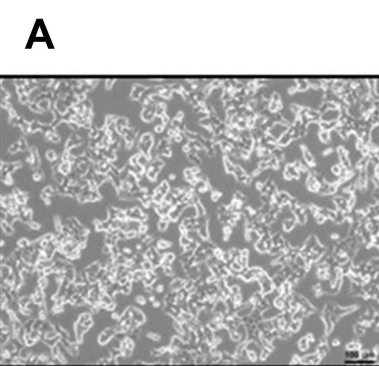

Control

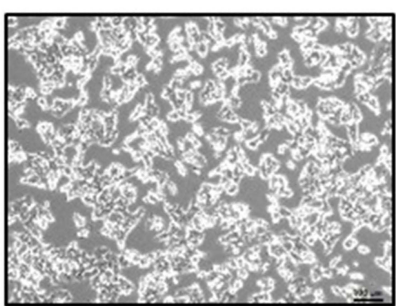

Tetrandrine $(1.25 \mu \mathrm{M})$

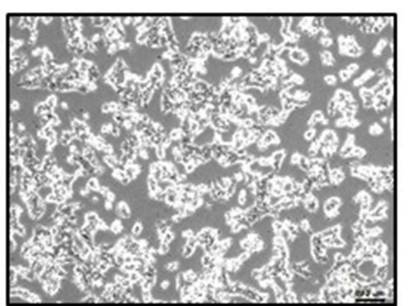

Tetrandrine $(2.5 \mu \mathrm{M})$

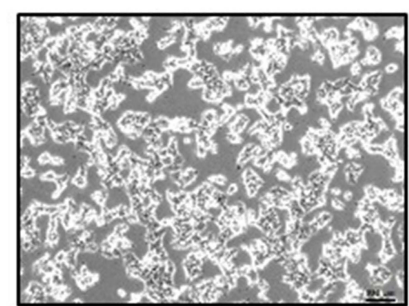

Tetrandrine $(5 \mu \mathrm{M})$

HCT116

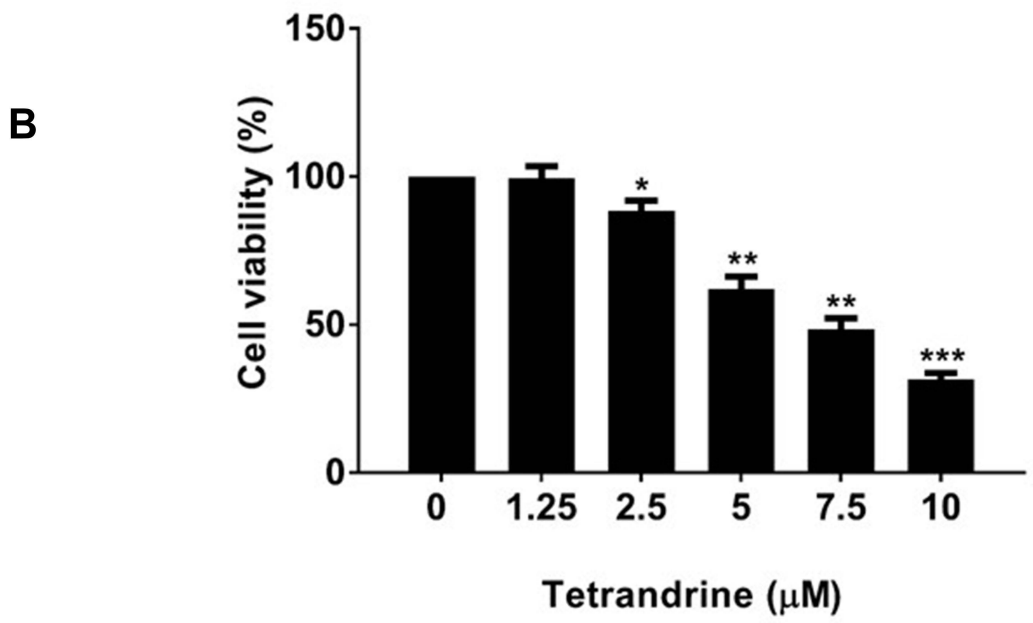

Figure I Tetrandrine inhibits the survival of HCTII6 cells. (A) Morphology of HCTII6 cells was analyzed following the treatment with different concentrations of tetrandrine (as indicated) for $24 \mathrm{~h}$. (B) Following the treatment with different concentrations of tetrandrine for $24 \mathrm{~h}$, HCTII6 cell proliferation was analyzed using an MTT assay. The $\mathrm{IC}_{50}$ value of tetrandrine was found to be $7.2 \mu \mathrm{M}$. The results were obtained from at least three independent experiments and the data are presented as the mean $\pm \mathrm{SD}$. $* \mathrm{P}<0.05$, $* * \mathrm{P}<0.0 \mathrm{I}, * * * \mathrm{P}<0.00 \mathrm{I}$ vs control.

was reduced from 1.7 -fold to 1.2 -fold at $5 \mu \mathrm{M}$ tetrandrine treatment compared with the control cells, respectively (Figure 3A-C).

\section{Tetrandrine Regulates the Expression of Metastasis-Related Genes}

Tetrandrine was reported to downregulate the expression of metastasis-related proteins in cancer cells. ${ }^{29}$ The expression of E-cadherin is often recognized as an important hallmark of cancer cell metastasis. ${ }^{38}$ Positive regulators, such as FOXA1, were found to upregulate E-cadherin expression, while negative regulators, such as ZEB1, SNAIL and twist1, downregulated E-cadherin expression. RT-qPCR was used to investigate whether tetrandrine affected the mRNA expression levels of E-cadherin, FOXA1 and ZEB1 in IL-6-induced HCT116 cells. As shown in Figure 4A, tetrandrine significantly upregulated the expression levels of E-cadherin and FOXA1. Conversely, the expression levels of ZEB1 were downregulated, and the expression levels of SNAIL and twist1 were slightly altered by tetrandrine. Western blotting was used to further determine whether tetrandrine affected the protein expression levels of E-cadherin, FOXA1 and ZEB1 in IL-6-induced HCT116 cells. The data revealed that tetrandrine significantly upregulated the expression levels of E-cadherin and FOXA1. Conversely, tetrandrine downregulated the expression levels of p-STAT3, which led to the downregulation of ZEB1 expression (Figure 4B and C).

\section{Promoter Activity of E-Cadherin is Regulated by Tetrandrine}

Negative regulators, such as SNAIL, $^{39}$ twis $^{40}$ and ZEB $1,{ }^{13}$ were found to bind to E-box, and several E-box DNA sequences are located in the promoter of E-cadherin. The four major E-box binding sites of E-cadherin are located at $-926 /-921,-642 /-637,-466 /-461$ and $-294 /-$ 
A

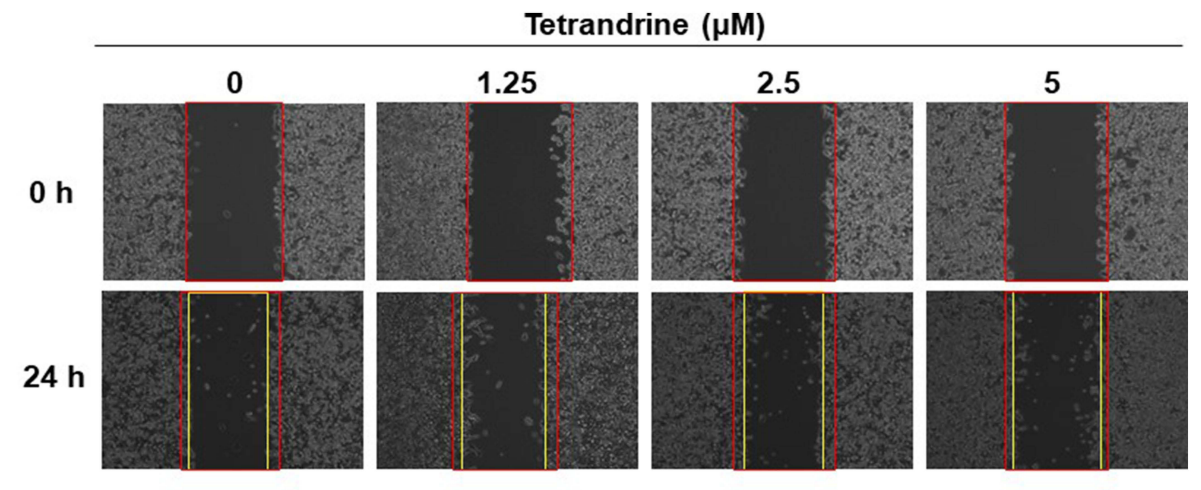

B
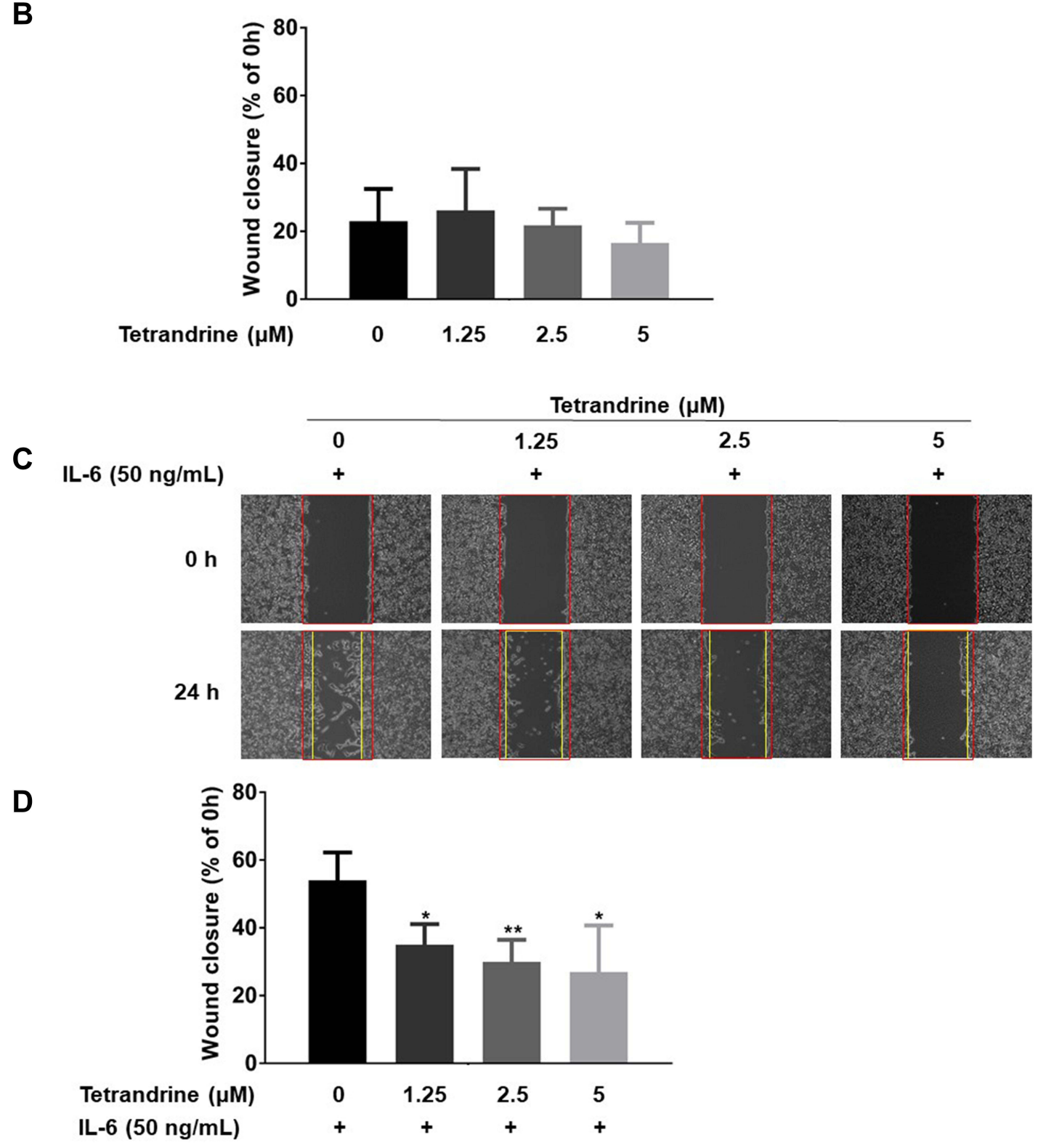

Figure 2 Tetrandrine inhibit the migration of HCTII 6 cells. (A) Following treatment with different concentrations of tetrandrine (as indicated) for 24 h, the migration of HCTII 6 cells was evaluated using a wound healing assay. (B) Semi-quantification of migration from part (A). (C) Following stimulation with 50 ng/mL IL-6 and treatment with different concentrations of tetrandrine (as indicated) for $24 \mathrm{~h}$, the migration of HCTII6 cells was evaluated using a wound healing assay. (D) Semi-quantification of migration from part (C). The results were from at least three independent experiments and the data are presented as the mean $\pm \mathrm{SD}$. $* \mathrm{P}<0.05$, $* * \mathrm{P}<0.0 \mathrm{I}$ vs control. 


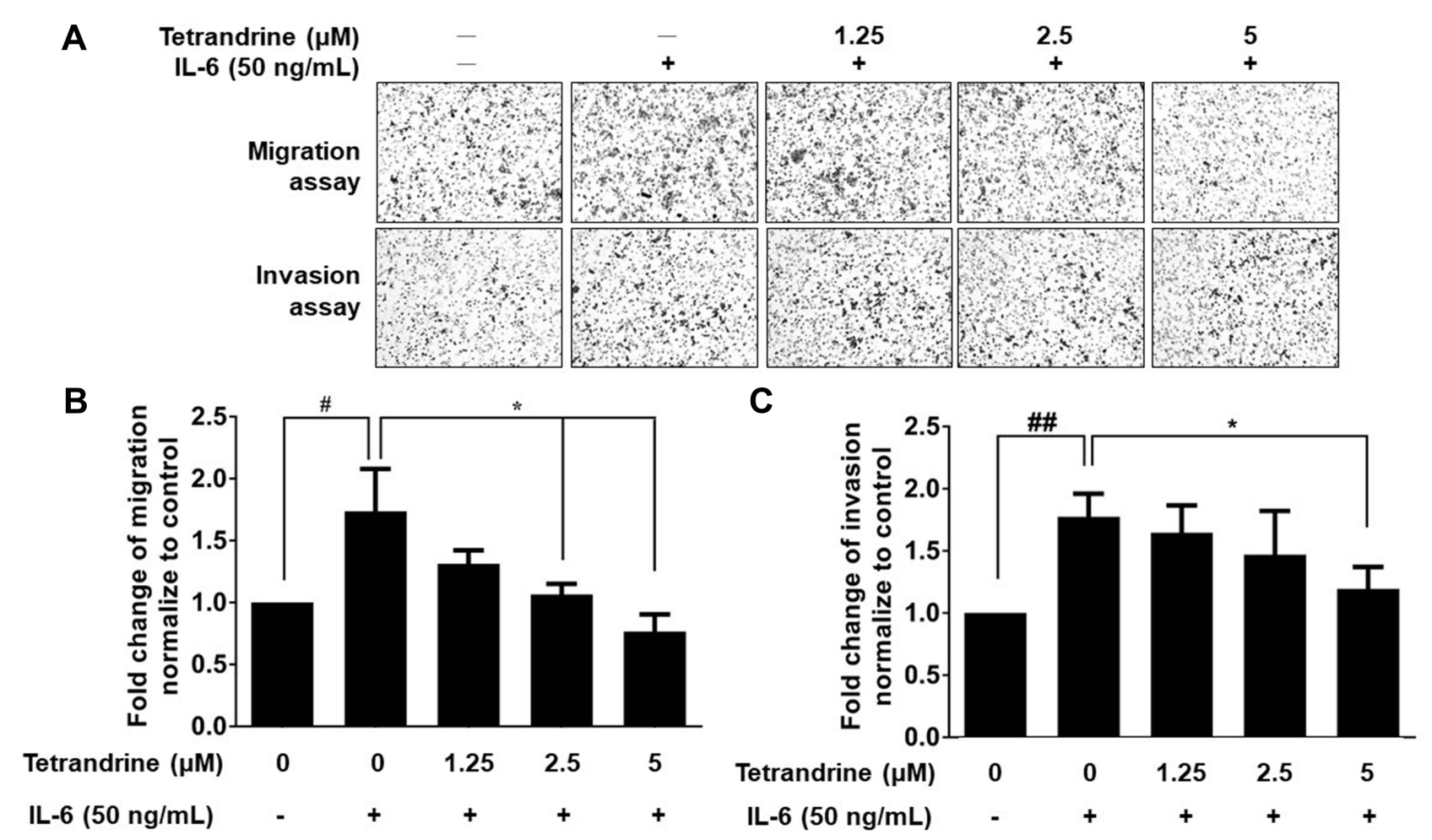

Figure 3 Tetrandrine inhibits the migration and invasion of IL-6-stimulated HCTII6 cells. (A) Following stimulation with 50 ng/mL IL-6 and treatment with different concentrations of tetrandrine (as indicated) for $24 \mathrm{~h}$, the migration and invasion of HCTI 16 cells were evaluated using Transwell assays. (B) Semi-quantification of migration from part (A). (C) Semi-quantification of invasion from part (A). The results were obtained from at least three independent experiments and the data are presented as the mean \pm SD. $* \mathrm{P}<0.05$ vs control, ${ }^{\#} \mathrm{P}<0.05$ vs control and ${ }^{\# \#} \mathrm{P}<0.0 \mathrm{l}$ vs control.

289. Four different lengths of the E-cadherin promoter were constructed and shown in Figure 5A. To determine which E-box was important for the activity of the E-cadherin promoter, a dual luciferase reporter assay was performed. The results revealed that the promoter activity of P3 was significantly 3-fold lower than that of $\mathrm{P} 2$, while the promoter activity of P4 was significantly 2.5-fold higher than that of $\mathrm{P} 3$, which indicated that E-box 3 may be the key target to regulate E-cadherin in HCT116 cells (Figure 5A). To determine the importance of E-box 3 for the regulation of E-cadherin, an E-box 3 mutant, P3.1, was constructed. The results demonstrated that the E-cadherin promoter activity was significantly increased in the mutant, P3.1, which suggested that E-box 3 may play a vital role in regulating E-cadherin expression (Figure 5A).

To investigate whether tetrandrine reverted the activity of the P3 promoter in IL-6-induced HCT116 cells, the P3 promoter was transfected into HCT116 cells for $24 \mathrm{~h}$, followed by IL- 6 induction and tetrandrine treatment as indicated for another $24 \mathrm{~h}$. The results found that the P3 promoter activity was in a 0.2 -fold increase after cells were treated with either 2.5 or $5 \mu \mathrm{M}$ tetrandrine (Figure 5B).

\section{Tetrandrine Downregulates MMP-2 Expression and Enzyme Activity in IL-6-Stimulated HCTII6 Cells}

MMPs have been discovered to play an important role in cancer progression and metastasis. ${ }^{41}$ In CRC, the upregulation of MMP-2 expression levels was found to be associated with a poor prognosis. $^{42}$ To determine whether tetrandrine affected the enzyme activity and expression of MMP-2 in IL-6-stimulated HCT116 cells, a zymography assay and RT-qPCR were performed. The enzyme activity of MMP-2 significantly inhibited from 1.4-fold to 0.8 -fold at $5 \mu \mathrm{M}$ tetrandrine treatment in IL6 -stimulated HCT116 cells, as determined using the zymography assay (Figure 6A and B). The $\alpha$ and $\beta$ subtypes of HSP90 were previously discovered to assist MMP-2 activation, thereby promoting cancer cell invasion. ${ }^{43}$ To further verify the mechanism of MMP-2 activation in the present study, RT-qPCR was used to examine the expression levels of MMP-2 and HSP90B1 in IL-6-stimulated 


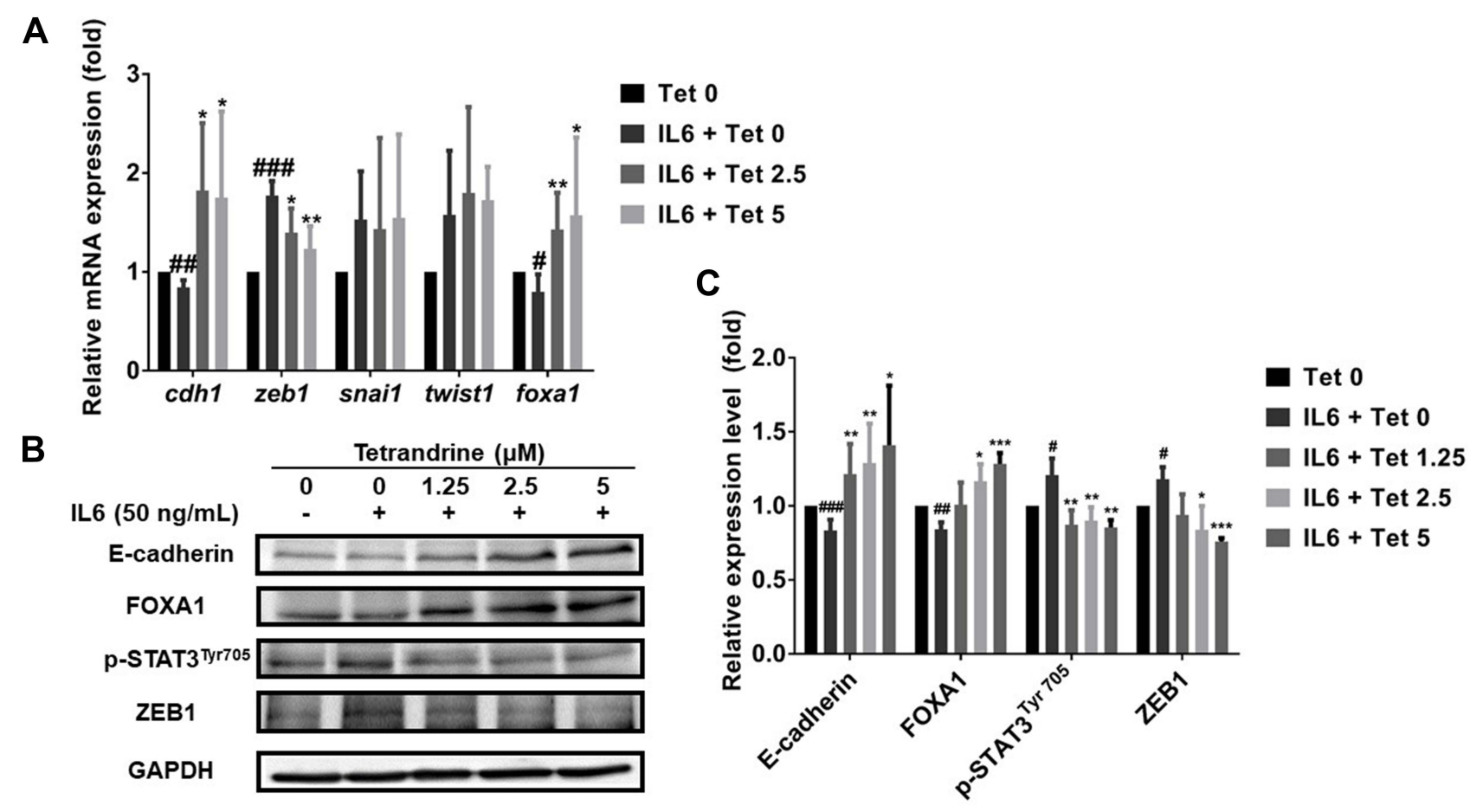

Figure 4 Tetrandrine regulates the expression of migration-related genes in IL-6-stimulated HCTII6 cells. (A) Expression levels of migration-related genes (E-cadherin, ZEBI, SNAIL, twistl and FOXAI) in IL-6-stimulated HCTII6 cells with or without tetrandrine treatment were assessed using reverse transcription-quantitative PCR. GAPDH was used as the internal control. (B) Expression levels of migration-related proteins (E-cadherin, FOXAI, P-STAT3 and ZEBI) in IL-6-stimulated HCTII6 cells with or without tetrandrine treatment were analyzed using Western blotting. GAPDH was used as the internal loading control. (C) Semi-quantitative analysis of part (B). The results were obtained from at least three independent experiments and the data are presented as the mean \pm SD. ${ }^{\#} P<0.05$, ${ }^{\# \prime} P<0.01$ and ${ }^{\# \#} P<0.001$ vs control. ${ }^{*} P<0.05$, $* * \mathrm{P}<0.0 \mathrm{I}, * * * \mathrm{P}<0.00 \mathrm{I}$ vs control.

Abbreviations: ZEBI, zinc finger E-box binding homeobox I; SNAIL, snail family transcriptional repressor I; twistl, twist family bHLH transcription factor I; FOXAI, forkhead box Al; p-, phosphorylated.

HCT116 cells. The results showed that tetrandrine significantly downregulated the mRNA expression levels of MMP-2 and HSP90B1 (Figure 6C). These findings suggested that tetrandrine may downregulate MMP-2 enzyme activity by downregulating HSP90B1 gene expression.

\section{Discussion}

In recent years, safety concerns regarding the association between certain foods and the occurrence of CRC have been raised. Surgery and chemotherapy are common methods for the treatment of early CRC. However, if CRC metastasizes or progresses to stage IV, the disease is difficult to cure. Although chemotherapy drugs commonly used in the clinic prolong survival, the side effects of the drugs often cause severe discomfort to the patients. Therefore, it remains an urgent priority to identify drugs that can effectively inhibit the metastasis of CRC and have a tolerable side effect profile.

Natural extracts have been found to inhibit the proliferation, survival and metastasis of cancer cells. For example, curcumin inhibited the proliferation and metastasis of oral cancer cells. ${ }^{44}$ Tetrandrine, an alkaloid extracted from the root of Stephania tetrandra, is commonly used in the treatment of rheumatoid arthritis. The side effects of tetrandrine are mild nausea and upper abdominal discomfort. Tetrandrine caused cell cycle arrest $\mathrm{t}^{45}$ and inhibited proliferation in colon cancer cells in vitro. ${ }^{46-48}$ In addition, tetrandrine induced apoptosis in vitro and in vivo. ${ }^{49,50} \mathrm{~A}$ previous study reported that tetrandrine inhibited the metastasis of CRC $;{ }^{51}$ however, to the best of our knowledge, the molecular mechanism has yet to be investigated. The two-way communication between cancer cells and the tumor microenvironment was found to regulate cell proliferation and metastasis. ${ }^{52}$ In the tumor microenvironment, cells secrete cytokines and chemotactic molecules to influence each other, which enhances cancer cell metastasis. IL-6 was discovered to promote the metastasis of a variety of cancer cell types. In fact, the poor prognosis of patients with CRC in the clinic was found to be associated with the high activity of IL- $6 .{ }^{53}$ The present study used HCT116 CRC cells, which have a low migratory ability, to demonstrate 
A

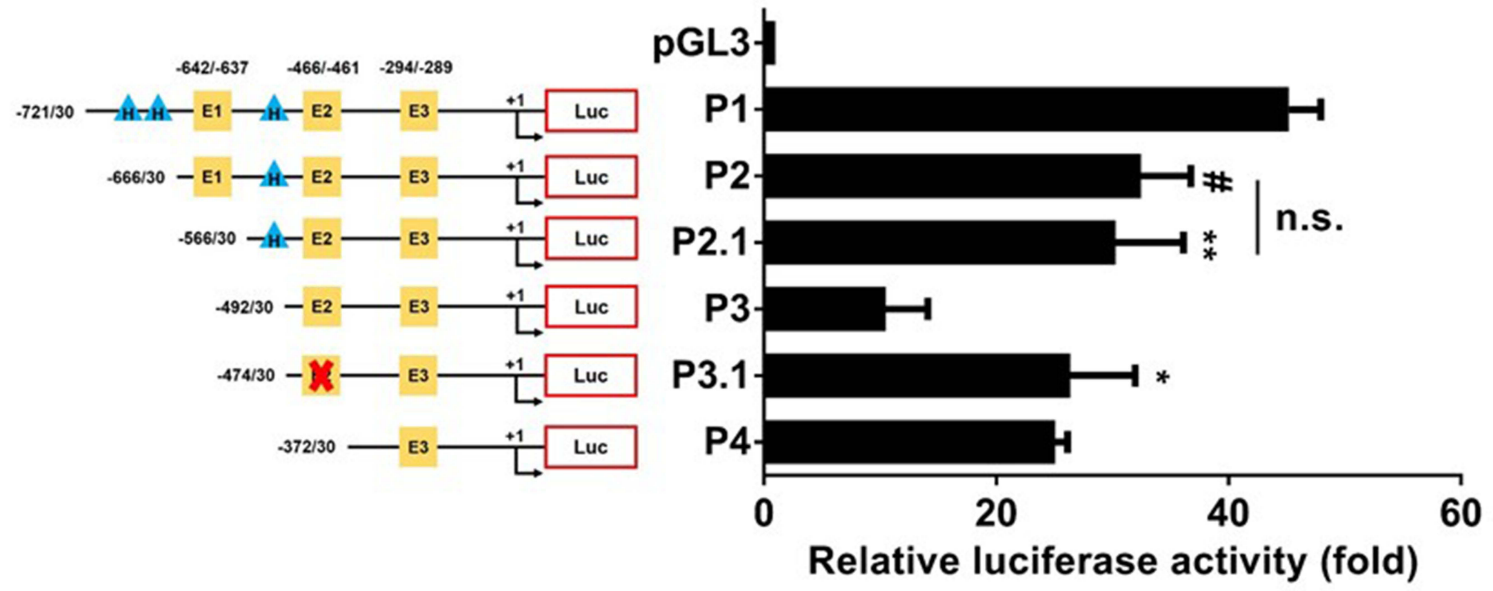

B

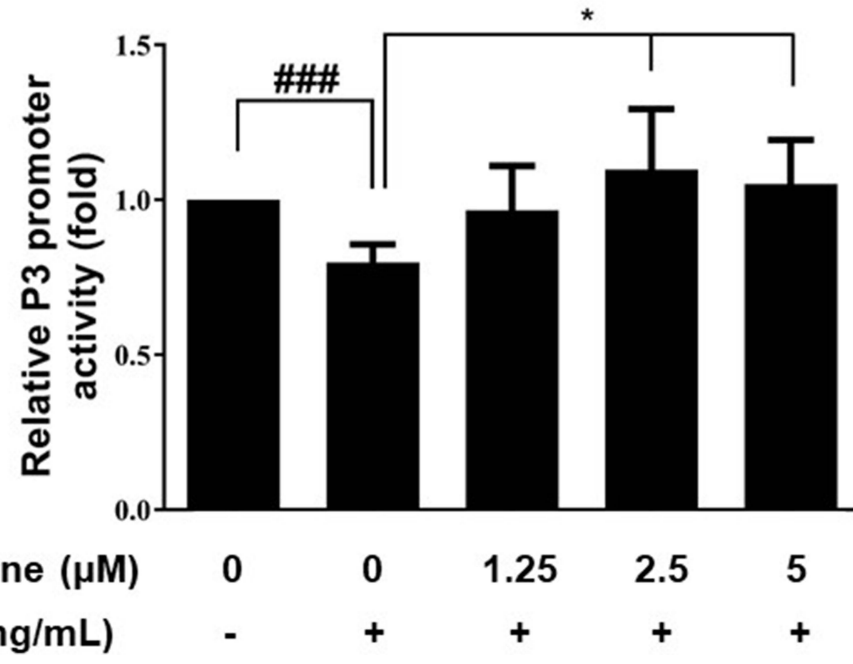

Figure 5 Tetrandrine restores the P3 promoter activity of E-cadherin in IL-6-stimulated HCTII6 cells. (A) The four major E-box binding sites of E-cadherin are located at $-926 /-921,-642 /-637,-466 /-46 I$ and -294/-289. Different lengths of the E-cadherin promoter were constructed and cloned into a pGL3-basic vector. E-box 3 mutant, P3.I, was also constructed. A variety of constructs were transfected into HCTII6 cells for $48 \mathrm{~h}$, and the cells were harvested for analysis of promoter activity using a dual luciferase reporter assay. (B) E-box 3, P3, was transfected into HCTII6 cells for 24 h, and the cells were subsequently stimulated with 50 ng/mL IL-6 and treated with 0 , I.25, 2.5 or $5 \mu \mathrm{M}$ tetrandrine. Cells were harvested for analysis of promoter activity using a dual luciferase reporter assay. The results were obtained from at least three independent experiments and the data are presented as the mean $\pm \mathrm{SD}$. ${ }^{*} \mathrm{P}<0.05$, ${ }^{* * P}<0.01$, vs control; ${ }^{\#} \mathrm{P}<0.05$, ${ }^{\# \#} \mathrm{P}<0.00 \mathrm{I}$ vs control, ns- not significant.

Abbreviation: E-box, enhancer box.

that tetrandrine could regulate the IL-6-induced molecular mechanism of CRC cell metastasis.

The effect of tetrandrine on the viability of HCT116 cells was evaluated using an MTT assay. The present results revealed that $7.2 \mu \mathrm{M}$ tetrandrine reduced the survival rate of HCT116 cells to $50 \%$, and $1.25,2.5$ and $5 \mu \mathrm{M}$ tetrandrine induced slight morphological changes in HCT116 cells. Previous studies have shown that low concentrations of tetrandrine have no significant toxic effect on normal cells. For example, 6-15 $\mu \mathrm{M}$ tetrandrine did not cause apoptosis in MCF-10A breast epithelial cells. In addition, $30 \mu \mathrm{M}$ tetrandrine only induced death in $2.9-9.5 \%$ of PWR-1E normal prostate epithelial cells. ${ }^{54}$ The present study selected tetrandrine doses of $1.25,2.5$ and $5 \mu \mathrm{M}$ to treat HCT116 cells in experiments investigating metastasis-related functions. Previous study demonstrated tetrandrine inhibited pulmonary metastases in animal study. ${ }^{55}$ In the future, further investigation should be performed to explore the toxic effects of tetrandrine on normal colonic cells and in vivo animal study.

To examine whether tetrandrine affected the migration and invasion of HCT116 cells, wound healing and Transwell assays, respectively, were used. Tetrandrine slightly inhibited the migration of HCT116 cells, while IL-6 increased HCT116 cell migration. In addition, the results of the Transwell assays further demonstrated that tetrandrine significantly inhibited the migration and invasion of IL-6-stimulated HCT116 cells. These results suggested that tetrandrine may have the potential to inhibit the 
A

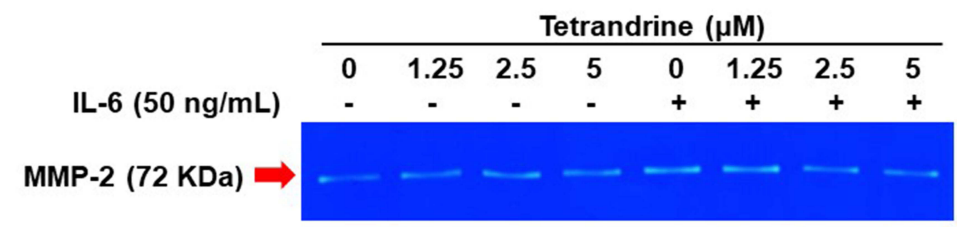

B

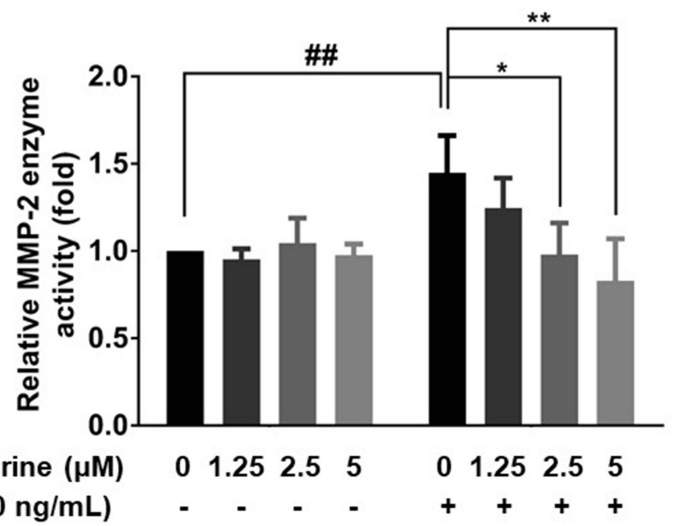

C

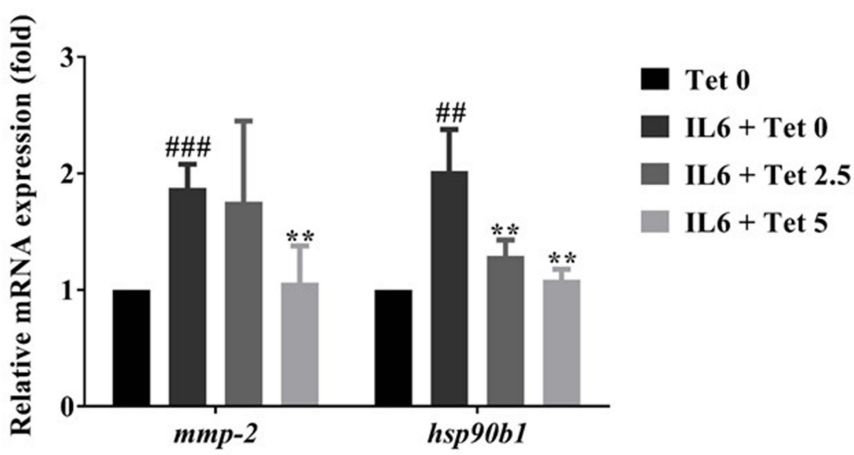

Figure 6 Tetrandrine significantly inhibits MMP-2 enzyme activity in IL-6-stimulated HCTII 6 cells. (A) HCTII 6 cells were treated with 0 , I.25, 2.5 or $5 \mu$ M tetrandrine in the absence or presence of IL-6 for $24 \mathrm{~h}$. Culture media was harvested and MMP enzyme activity was analyzed using a zymography assay. (B) Quantitative analysis of part (A) is presented. (C) HCTII 6 cells were treated with $0,1.25,2.5$ or $5 \mu \mathrm{M}$ tetrandrine in the absence or presence of IL-6 for $24 \mathrm{~h}$. Cells were harvested and the expression levels of MMP-2 and HSP90BI were analyzed using reverse transcription-quantitative PCR. The results were obtained from four independent experiments and the data are presented as the mean $\pm \mathrm{SD}$. ${ }^{*} \mathrm{P}<0.05$, ${ }^{* *} \mathrm{P}<0.0$ I vs control; ${ }^{\# \#} \mathrm{P}<0.0 \mathrm{I}$, ${ }^{\# \#} \mathrm{P}<0.00$ I vs control.

Abbreviation: $\mathrm{HSP} 90 \mathrm{BI}$, heat shock protein $90 \beta$ family member $\mathrm{I}$.

migration and invasion of cancer cells influenced by the tumor microenvironment.

EMT is an important process required for the metastasis of numerous types of cancer cell. When cancer cells change from an epithelial to a mesenchymal phenotype, they are often accompanied by changes in the expression of several proteins; for example, E-cadherin can be used as an indicator protein of EMT. The downregulation of E-cadherin expression was found to play an important role in the induction of cancer cell metastasis. ${ }^{56}$ The expression levels of E-cadherin are related to the interaction between the E-cadherin promoter and transcription factors and a number of negative and positive regulators will affect E-cadherin transcription. For example, the E-boxes in the E-cadherin promoter are the binding sites of negative regulators, such as ZEB1, Twist1 and SNAIL, and the interaction between negative regulators and the E-box was reported to downregulate E-cadherin transcription. ${ }^{57}$ Conversely, the interaction between positive regulators, such as FOXA1 (HNF3 $\alpha$ ), and the E-cadherin promoter upregulated E-cadherin transcription. $^{58}$ In the present study, RT-qPCR and Western blotting data revealed that the mRNA and protein expression levels, respectively, of E-cadherin and FOXA1 were downregulated in IL-6-stimulated HCT116 cells, while the mRNA and protein expression levels of E-cadherin and FOXA1 were upregulated following the treatment with tetrandrine. In addition, the mRNA and protein expression levels of ZEB1 were upregulated in IL-6-stimulated HCT116 cells, while the mRNA and protein expression levels of ZEB1 were downregulated following the treatment with tetrandrine. Moreover, no significant changes were observed in the mRNA and protein expression levels of SNAIL and twist1 in the IL-6-stimulated and tetrandrine-treated HCT116 cells. STAT3 is induced by IL-6. The phosphorylation of STAT3 at tyrosine 705 (STAT3 ${ }^{\text {Tyr705}}$ ) enables it to enter the nucleus and trigger downstream gene transcription. p-STAT3 ${ }^{\text {Tyr705 }}$ interacts with ZEB1 and binds to the promoter of E-cadherin, which results in the upregulation of E-cadherin expression. ${ }^{59}$ The Western blotting data of the present study further demonstrated that the expression levels of p-STAT3 ${ }^{\text {Tyr705 }}$ and ZEB1 were similar. Tetrandrine upregulated FOXA1 expression levels and downregulate the expression levels of p-STAT3 ${ }^{\text {Tyr705, which }}$ resulted in the downregulated 


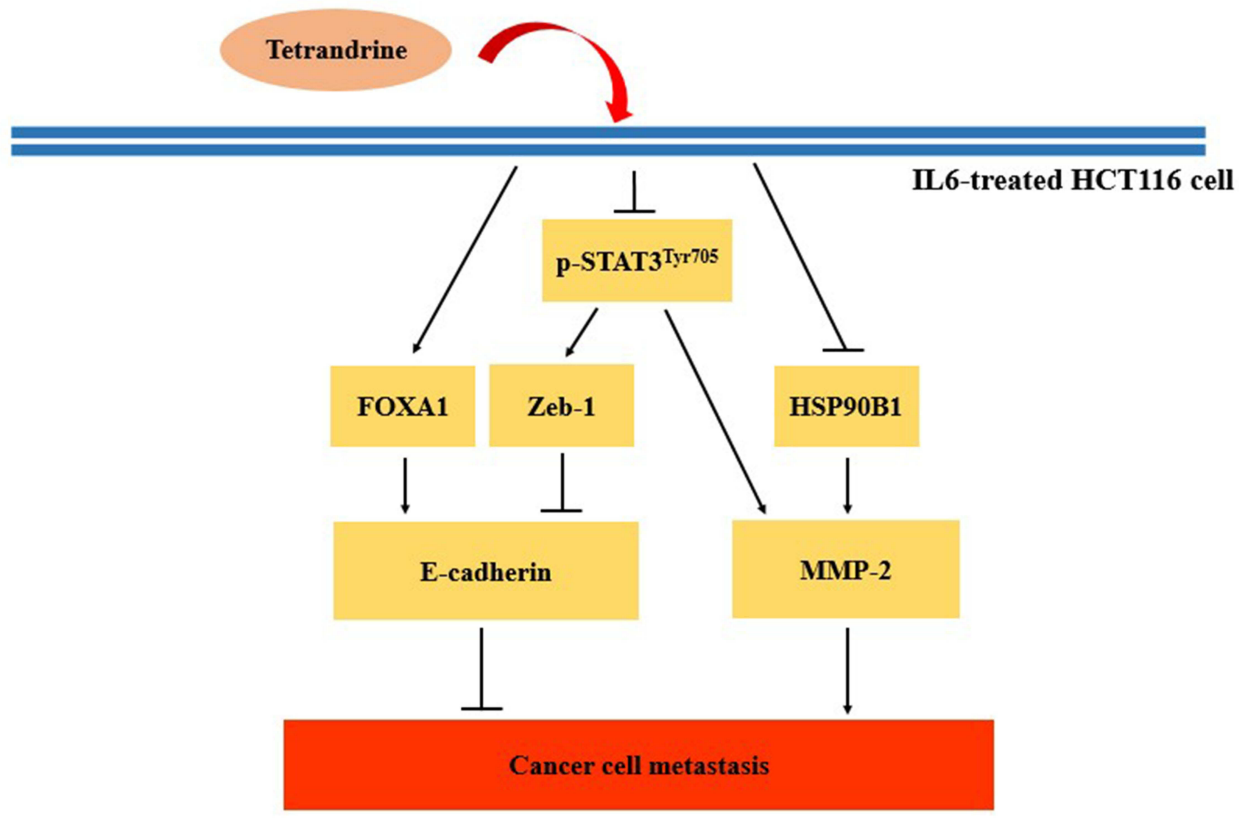

Figure 7 Schematic diagram of the mechanism of action of tetrandrine in IL-6-stimulated HCTII6 cells. HCTII6 cells were stimulated with IL-6 and treated with tetrandrine. FOXAI expression levels were upregulated and ZEBI expression levels were downregulated via the inhibition of $\mathrm{p}-\mathrm{STAT} 3^{\mathrm{Ty}} \mathrm{r05}$, which led to the recovery of E-cadherin expression and the inhibition of cell migration. In addition, tetrandrine downregulated the expression of $\mathrm{P}-\mathrm{STAT3} 3^{\mathrm{Ty}} \mathrm{705}$ and $\mathrm{HSP} 90 \mathrm{BI}$, resulting in the downregulation of MMP-2 expression and enzyme activity. The experimental results suggested that tetrandrine may inhibit IL-6-induced HCTII6 cell metastasis. Abbreviations: FOXAI, forkhead box AI; p-, phosphorylated; Tyr705, tyrosine 705; HSP90BI, heat shock protein $90 \beta$ family member I.

expression of ZEB1 and ultimately, the upregulation of E-cadherin expression and inhibition of cancer metastasis (Figure 7).

E-cadherin expression is an important hallmark of cancer cell metastasis. E-box regulatory elements of the E-cadherin promoter interact with negative regulators, which was discovered to result in downregulated E-cadherin expression and the induction of cancer cell metastasis. The four E-boxes of the E-cadherin promoter are located at -926/-921, -642/$637,-466 /-461$ and $-294 /-289$. The present study investigated the binding of the negative transcriptional regulator, ZEB1, to the E-box P3, located at $-466 /-461$, which was discovered to represses E-cadherin transcription. To characterize the role of E-box P3, an E-box P3 mutant, denoted as P3.1, was constructed. The results revealed that the binding site of the negative regulators was E-box P3. Notably, tetrandrine significantly increased the activity of the $\mathrm{P} 3$ promoter in IL-6-stimulated HCT116 cells. Tetrandrine also downregulated the expression levels of ZEB1 and reactivated the promoter of E-cadherin, which led to the reduction in cancer metastasis.

MMPs are also important for the progression and metastasis of cancers. The upregulated expression of MMP-2 and MMP-9 was discovered to be associated with the poor prognosis of patients with $\mathrm{CRC} .^{42,60}$ To determine whether tetrandrine affected the expression and enzyme activity of MMP-2 and MMP-9 in HCT116 cells, the present study performed RT-qPCR and zymography assays. The results revealed that tetrandrine significantly inhibited the enzyme activity of MMP-2 in IL-6-stimulated HCT116 cells. It is the consistent with the previous study in colon cancer SW620 cells. ${ }^{60}$ However, the expression of MMP-9 is very low in HCT116 cells; therefore, the current study was unable to quantify the enzyme activity of MMP-9 in IL-6-stimulated HCT116 cells, unlike a previous study. ${ }^{61}$ The $\alpha$ and $\beta$ subtypes of HSP90 are known to activate MMP-2. In the current study, tetrandrine was discovered to significantly downregulate MMP-2 and HSP90B1 mRNA expression levels in IL6-stimulated HCT116 cells. A previous study demonstrated that MMP-2 was a target protein of STAT3 regulation; p-STAT3 entered the nucleus and bound to the MMP-2 gene promoter, which upregulated MMP-2 expression. ${ }^{62}$ In the present study, tetrandrine downregulated the expression of p-STAT3 ${ }^{\text {Tyr705, }}$, which resulted in the downregulation of MMP-2 expression.

In conclusion, the findings of the present study suggested that tetrandrine may inhibit IL-6-induced CRC metastasis; however, the exact underlying mechanism of action requires further investigations. For example, the interaction between E-box P3 and ZEB1 could be characterized using chromatin 
immunoprecipitation assays and the tetrandrine-induced inhibition of IL-6-induced CRC metastasis should be investigated in an in vivo mouse model.

\section{Ethics Approval and Consent to Participate}

This study does not contain any studies with human participants performed by any of the authors.

\section{Patient Consent for Publication}

No patients are involved.

\section{Acknowledgments}

We would like to thank the Office of Research \& Development at China Medical University, Taichung, Taiwan, R.O.C. for the use of the Medical Research Core Facilities to perform the experiments and data analysis.

\section{Funding}

The present study was supported, in part, by grants awarded from Dr. Shih-Chang Tsai of China Medical University (grant nos. CMU-103-S-16 and MOST 1062314-B-039-046).

\section{Disclosure}

The authors declare that they have no conflicts of interest for this work.

\section{References}

1. Jiang WG, Sanders AJ, Katoh M, et al. Tissue invasion and metastasis: molecular, biological and clinical perspectives. Semin Cancer Biol. 2015;35(Suppl):S244-S275. doi:10.1016/j.semcancer.2015.03.008

2. Ye X, Brabletz T, Kang Y, et al. Upholding a role for EMT in breast cancer metastasis. Nature. 2017;547(7661):E1-E3. doi:10.1038/nature 22816

3. Paget $\mathrm{S}$. The distribution of secondary growths in cancer of the breast. 1889. Cancer Metastasis Rev. 1989;8(2):98-101.

4. Joyce JA, Pollard JW. Microenvironmental regulation of metastasis. Nat Rev Cancer. 2009;9(4):239-252. doi:10.1038/nrc2618

5. Okada N, Kobayashi M, Mugikura K, et al. Interleukin-6 production in human fibroblasts derived from periodontal tissues is differentially regulated by cytokines and a glucocorticoid. $J$ Periodontal Res. 1997;32(7):559-569. doi:10.1111/j.1600-0765.1997.tb00932.x

6. Bussemakers MJ, van Bokhoven A, Voller M, Smit FP, Schalken JA. The genes for the calcium-dependent cell adhesion molecules P- and E-cadherin are tandemly arranged in the human genome. Biochem Biophys Res Commun. 1994;203(2):1291-1294. doi:10.1006/bbrc.19 94.2322

7. Jamora C, Fuchs E. Intercellular adhesion, signalling and the cytoskeleton. Nat Cell Biol. 2002;4(4):E101-8. doi:10.1038/ncb0402e101

8. Humphries MJ, Newham P. The structure of cell-adhesion molecules. Trends Cell Biol. 1998;8(2):78-83. doi:10.1016/S0962-8924(97)011 $88-4$
9. Kim SA, Inamura K, Yamauchi M, et al. Loss of CDH1 (E-cadherin) expression is associated with infiltrative tumour growth and lymph node metastasis. Br J Cancer. 2016;114(2):199-206. doi:10.1038/ bjc. 2015.347

10. Cavallaro U, Christofori G. Cell adhesion and signalling by cadherins and Ig-CAMs in cancer. Nat Rev Cancer. 2004;4(2):118-132. doi:10.1038/nrc1276

11. Barrallo-Gimeno A, Nieto MA. The Snail genes as inducers of cell movement and survival: implications in development and cancer. Development. 2005;132(14):3151-3161. doi:10.1242/ dev.01907

12. Hajra KM, Chen DY, Fearon ER. The SLUG zinc-finger protein represses E-cadherin in breast cancer. Cancer Res. 2002;62 (6):1613-1618.

13. Wong TS, Gao W, Chan JY. Transcription regulation of E-cadherin by zinc finger E-box binding homeobox proteins in solid tumors. Biomed Res Int. 2014;2014:921564. doi:10.1155/2014/921564

14. Yang J, Mani SA, Donaher JL, et al. Twist, a master regulator of morphogenesis, plays an essential role in tumor metastasis. Cell. 2004;117(7):927-939. doi:10.1016/j.cell.2004.06.006

15. Vasen HF, Tomlinson I, Castells A. Clinical management of hereditary colorectal cancer syndromes. Nat Rev Gastroenterol Hepatol. 2015;12(2):88-97. doi:10.1038/nrgastro.2014.229

16. Vogelstein B, Fearon ER, Hamilton SR, et al. Genetic alterations during colorectal-tumor development. N Engl J Med. 1988;319 (9):525-532. doi:10.1056/NEJM198809013190901

17. Pelucchi C, Tramacere I, Boffetta P, Negri E, La Vecchia C. Alcohol consumption and cancer risk. Nutr Cancer. 2011;63(7):983-990. doi:10.1080/01635581.2011.596642

18. Kuipers EJ, Grady WM, Lieberman D, et al. Colorectal cancer. Nature Rev Dis Prim. 2015;1:15065. doi:10.1038/nrdp.2015.65

19. Tol J, Koopman M, Cats A, et al. Chemotherapy, bevacizumab, and cetuximab in metastatic colorectal cancer. $N$ Engl J Med. 2009;360 (6):563-572. doi:10.1056/NEJMoa0808268

20. Schiff PL Jr. Bisbenzylisoquinoline alkaloids. J Nat Prod. 1987;50 (4):529-599. doi:10.1021/np50052a001

21. Lee YS, Han SH, Lee SH, et al. The mechanism of antibacterial activity of tetrandrine against Staphylococcus aureus. Foodborne Pathog Dis. 2012;9(8):686-691. doi:10.1089/fpd.2011.1119

22. Iturriaga-Vasquez $\mathrm{P}$, Miquel $\mathrm{R}$, Ivorra $\mathrm{MD}$, D'Ocon $\mathrm{MP}$, Cassels BK. Simplified tetrandrine congeners as possible antihypertensive agents with a dual mechanism of action. $J$ Nat Prod. 2003;66(7):954-957.

23. Shen DF, Tang QZ, Yan L, et al. Tetrandrine blocks cardiac hypertrophy by disrupting reactive oxygen species-dependent ERK1/2 signalling. Br J Pharmacol. 2010;159(4):970-981. doi:10.1111/ j.1476-5381.2009.00605.x

24. Wang HL, Kilfeather SA, Martin GR, Page CP. Effects of tetrandrine on growth factor-induced DNA synthesis and proliferative response of rat pulmonary artery smooth muscle cells. Pulm Pharmacol Ther. 2000;13(2):53-60. doi:10.1006/pupt.2000.0230

25. Ho LJ, Lai JH. Chinese herbs as immunomodulators and potential disease-modifying antirheumatic drugs in autoimmune disorders. Curr Drug Metab. 2004;5(2):181-192. doi:10.2174/138920004348 9081

26. Xie QM, Tang HF, Chen JQ, Bian RL. Pharmacological actions of tetrandrine in inflammatory pulmonary diseases. Acta Pharmacol Sin. 2002;23(12):1107-1113.

27. Chen Y, Chen JC, Tseng SH. Tetrandrine suppresses tumor growth and angiogenesis of gliomas in rats. Int $J$ Cancer. 2009;124 (10):2260-2269. doi:10.1002/ijc. 24208

28. Yu FS, Yu CS, Chen JC, et al. Tetrandrine induces apoptosis Via caspase-8, -9 , and -3 and poly (ADP ribose) polymerase dependent pathways and autophagy through beclin-1/ LC3-I, II signaling pathways in human oral cancer HSC-3 cells. Environ Toxicol. 2016;31 (4):395-406. doi:10.1002/tox.22053 
29. Zhang Y, Liu W, He W, et al. Tetrandrine reverses epithelial-mesenchymal transition in bladder cancer by downregulating Gli-1. Int $J$ Oncol. 2016;48(5):2035-2042. doi:10.3892/ ijo.2016.3415

30. N. B, K.r. C. Tetrandrine and cancer - An overview on the molecular approach. Biomed Pharmacother. 2018;97:624-632. doi:10.1016/j. biopha.2017.10.116

31. Yang JS, Lin CA, Lu CC, Wen YF, Tsai FJ, Tsai SC. Carboxamide analog ITR-284 evokes apoptosis and inhibits migration ability in human lung adenocarcinoma A549 cells. Oncol Rep. 2017;37 (3):1786-1792. doi:10.3892/or.2017.5374

32. Lin $\mathrm{CC}$, Chen $\mathrm{KB}$, Tsai $\mathrm{CH}$, et al. Casticin inhibits human prostate cancer DU 145 cell migration and invasion via Ras/Akt/NF-kappaB signaling pathways. $J$ Food Biochem. 2019;43(7):e12902. doi:10.1111/jfbc.12902

33. Tsai SC, Tsai MH, Chiu CF, et al. AMPK-dependent signaling modulates the suppression of invasion and migration by fenofibrate in CAL 27 oral cancer cells through NF-kappaB pathway. Environ Toxicol. 2016;31(7):866-876. doi:10.1002/tox.22097

34. Yang JS, Lee CY, Cho HC, et al. ITR284 modulates cell differentiation in human chronic myelogenous leukemia K562 cells. Oncol Rep. 2018;39(1):383-391. doi:10.3892/or.2017.6090

35. Kou B, Liu W, He W, et al. Tetrandrine suppresses metastatic phenotype of prostate cancer cells by regulating Akt/mTOR/MMP-9 signaling pathway. Oncol Rep. 2016;35(5):2880-2886. doi:10.3892/ or.2016.4649

36. Chang Q, Bournazou E, Sansone P, et al. The IL-6/JAK/Stat3 feed-forward loop drives tumorigenesis and metastasis. Neoplasia. 2013;15(7):848-862. doi:10.1593/neo.13706

37. Ara $T$, Declerck YA. Interleukin-6 in bone metastasis and cancer progression. Eur J Cancer. 2010;46(7):1223-1231. doi:10.1016/j. ejca.2010.02.026

38. Zeisberg M, Neilson EG. Biomarkers for epithelial-mesenchymal transitions. J Clin Invest. 2009;119(6):1429-1437. doi:10.1172/ JCI36183

39. Comijn J, Berx G, Vermassen P, et al. The two-handed E box binding zinc finger protein SIP1 downregulates E-cadherin and induces invasion. Mol Cell. 2001;7(6):1267-1278. doi:10.1016/S10972765(01)00260-X

40. Vesuna F, van Diest P, Chen JH, Raman V. Twist is a transcriptional repressor of E-cadherin gene expression in breast cancer. Biochem Biophys Res Commun. 2008;367(2):235-241. doi:10.1016/j. bbrc.2007.11.151

41. Kessenbrock K, Plaks V, Werb Z. Matrix metalloproteinases: regulators of the tumor microenvironment. Cell. 2010;141(1):52-67. doi:10.1016/j.cell.2010.03.015

42. Said AH, Raufman JP, Xie G. The role of matrix metalloproteinases in colorectal cancer. Cancers. 2014;6(1):366-375. doi:10.3390/ cancers 6010366

43. Stellas D, El Hamidieh A, Patsavoudi E. Monoclonal antibody 4C5 prevents activation of MMP2 and MMP9 by disrupting their interaction with extracellular HSP90 and inhibits formation of metastatic breast cancer cell deposits. BMC Cell Biol. 2010;11:51. doi:10.1186/ 1471-2121-11-51

44. Zhen L, Fan D, Yi X, Cao X, Chen D, Wang L. Curcumin inhibits oral squamous cell carcinoma proliferation and invasion via EGFR signaling pathways. Int J Clin Exp Pathol. 2014;7(10):6438-6446.

45. Meng LH, Zhang H, Hayward L, Takemura H, Shao RG, Pommier Y. Tetrandrine induces early G1 arrest in human colon carcinoma cells by down-regulating the activity and inducing the degradation of G1-S-specific cyclin-dependent kinases and by inducing p53 and p21Cip1. Cancer Res. 2004;64(24):9086-9092. doi:10.1158/00085472.CAN-04-0313
46. Zhou Y, Mu L, Liu XL, et al. Tetrandrine inhibits proliferation of colon cancer cells by BMP9/ PTEN/ PI3K/AKT signaling. Genes Dis. 2021;8(3):373-383. doi:10.1016/j.gendis.2019.10.017

47. Li J, Wang Q, Wang Z, et al. Tetrandrine inhibits colon carcinoma HT-29 cells growth via the Bcl-2/Caspase 3/PARP pathway and G1/S phase. Biosci Rep. 2019;39:BSR20182109. doi:10.1042/BSR2018 2109

48. Chen QZ, Li Y, Shao Y, et al. TGF-beta1/PTEN/PI3K signaling plays a critical role in the anti-proliferation effect of tetrandrine in human colon cancer cells. Int J Oncol. 2017;50(3):1011-1021. doi:10.3892/ ijo.2017.3875

49. Wu JM, Chen Y, Chen JC, Lin TY, Tseng SH. Tetrandrine induces apoptosis and growth suppression of colon cancer cells in mice. Cancer Lett. 2010;287(2):187-195. doi:10.1016/j.canlet.2009.06.009

50. Chen XL, Ren KH, He HW, Shao RG. Involvement of PI3K/AKT/ GSK3beta pathway in tetrandrine-induced G1 arrest and apoptosis. Cancer Biol Ther. 2008;7(7):1073-1078. doi:10.4161/cbt.7.7.6142

51. He BC, Gao JL, Zhang BQ, et al. Tetrandrine inhibits Wnt/beta-catenin signaling and suppresses tumor growth of human colorectal cancer. Mol Pharmacol. 2011;79(2):211-219. doi:10.1124/mol.110. 068668

52. Yang JD, Nakamura I, Roberts LR. The tumor microenvironment in hepatocellular carcinoma: current status and therapeutic targets. Semin Cancer Biol. 2011;21(1):35-43. doi:10.1016/j.semcancer. 2010.10.007

53. Waldner MJ, Foersch S, Neurath MF. Interleukin-6-a key regulator of colorectal cancer development. Int J Biol Sci. 2012;8 (9):1248-1253. doi:10.7150/ijbs.4614

54. Zhang Y, Wang C, Wang H, Wang K, Du Y, Zhang J. Combination of Tetrandrine with cisplatin enhances cytotoxicity through growth suppression and apoptosis in ovarian cancer in vitro and in vivo. Cancer Lett. 2011;304(1):21-32. doi:10.1016/j.canlet.2011.01.022

55. Chang KH, Liao HF, Chang $\mathrm{HH}$, et al. Inhibitory effect of tetrandrine on pulmonary metastases in CT26 colorectal adenocarcinoma-bearing BALB/c mice. Am J Chin Med. 2004;32(6):863-872. doi:10.1142/ S0192415X04002478

56. Cavallaro U, Christofori G. Multitasking in tumor progression: signaling functions of cell adhesion molecules. Ann N Y Acad Sci. 2004;1014:58-66. doi:10.1196/annals.1294.006

57. Polyak K, Weinberg RA. Transitions between epithelial and mesenchymal states: acquisition of malignant and stem cell traits. Nat Rev Cancer. 2009;9(4):265-273. doi:10.1038/nrc2620

58. Liu YN, Lee WW, Wang CY, Chao TH, Chen Y, Chen JH. Regulatory mechanisms controlling human E-cadherin gene expression. Oncogene. 2005;24(56):8277-8290. doi:10.1038/sj. onc. 1208991

59. Xiong H, Hong J, Du W, et al. Roles of STAT3 and ZEB1 proteins in E-cadherin down-regulation and human colorectal cancer epithelial-mesenchymal transition. J Biol Chem. 2012;287(8):58 19-5832. doi:10.1074/jbc.M111.295964

60. Juan TK, Liu KC, Kuo CL, et al. Tetrandrine suppresses adhesion, migration and invasion of human colon cancer SW620 cells via inhibition of nuclear factor-kappaB, matrix metalloproteinase-2 and matrix metalloproteinase-9 signaling pathways. Oncol Lett. 2018;15 (5):7716-7724. doi:10.3892/ol.2018.8286

61. Wang L, Kuang L, Pan X, et al. Isoalvaxanthone inhibits colon cancer cell proliferation, migration and invasion through inactivating Rac1 and AP-1. Int $j$ Cancer. 2010;127(5):1220-1229. doi:10.1002/ijc. 25119

62. Kesanakurti D, Chetty C, Dinh DH, Gujrati M, Rao JS. Role of MMP-2 in the regulation of IL-6/Stat3 survival signaling via interaction with $\alpha 5 \beta 1$ integrin in glioma. Oncogene. 2013;32(3):327-340. doi:10.1038/onc.2012.52 


\section{Publish your work in this journal}

OncoTargets and Therapy is an international, peer-reviewed, open access journal focusing on the pathological basis of all cancers, potential targets for therapy and treatment protocols employed to improve the management of cancer patients. The journal also focuses on the impact of management programs and new therapeutic

Submit your manuscript here: https://www.dovepress.com/oncotargets-and-therapy-journal agents and protocols on patient perspectives such as quality of life, adherence and satisfaction. The manuscript management system is completely online and includes a very quick and fair peer-review system, which is all easy to use. Visit http://www.dovepress.com/ testimonials.php to read real quotes from published authors. 